\title{
Regulation of the Yersinia type III secretion system: traffic control
}

\section{Rebecca S. Dewoody, Peter M. Merritt and Melanie M. Marketon*}

Department of Biology, Indiana University, Bloomington, IN, USA

\section{Edited by:}

Matthew Francis, Umeå University,

Sweden

\section{Reviewed by:}

Ake Forsberg, Umeå University,

Sweden

Ina Attree, CNRS, France

*Correspondence:

Melanie M. Marketon, Department

of Biology, Indiana University,

1001 E. 3rd St., Bloomington,

IN 47405, USA.

e-mail: mmarketo@indiana.edu
Yersinia species, as well as many other Gram-negative pathogens, use a type III secretion system (T3SS) to translocate effector proteins from the bacterial cytoplasm to the host cytosol. This T3SS resembles a molecular syringe, with a needle-like shaft connected to a basal body structure, which spans the inner and outer bacterial membranes. The basal body of the injectisome shares a high degree of homology with the bacterial flagellum. Extending from the T3SS basal body is the needle, which is a polymer of a single protein, YscF. The distal end of the needle serves as a platform for the assembly of a tip complex composed of LcrV. Though never directly observed, prevailing models assume that LcrV assists in the insertion of the pore-forming proteins YopB and YopD into the host cell membrane. This completes a bridge between the bacterium and host cell to provide a continuous channel through which effectors are delivered. Significant effort has gone into understanding how the T3SS is assembled, how its substrates are recognized and how substrate delivery is controlled. Arguably the latter topic is the least understood; however, recent advances have provided new insight, and therefore, this review will focus primarily on summarizing the current state of knowledge regarding the control of substrate delivery by the T3SS. Specifically, we will discuss the roles of YopK, as well as YopN and YopE, which have long been linked to regulation of translocation. We also propose models whereby the YopK regulator communicates with the basal body of the T3SS to control translocation.

Keywords: type III secretion, injectisome, substrate specificity, YopK, YopE, YopN

\section{INTRODUCTION}

Pathogenic Yersinia species cause human diseases ranging from relatively mild intestinal disease for Yersinia pseudotuberculosis and Yersinia enterocolitica (Galindo et al., 2011) to bubonic plague for Yersinia pestis (Perry and Fetherston, 1997). Despite the differences in disease, virulence of these Yersinia species requires a conserved type III secretion system (T3SS) that has become a well-established model system for this form of protein secretion. Though first described in Yersinia, type III secretion is a conserved virulence factor amongst many human pathogens such as enteropathogenic Escherichia coli (EPEC), enterohemorrhagic Escherichia coli (EHEC), Salmonella sp., Pseudomonas aeruginosa, Shigella flexneri, and Chlamydia sp., which collectively cause significant healthcare costs annually (for recent reviews of these organisms, see Schroeder and Hilbi, 2008; Agbor and McCormick, 2011; Dean, 2011; Wong et al., 2011). The T3SS has been described as a molecular syringe that delivers cytotoxic effectors into host cells. Because this virulence mechanism is conserved in so many pathogenic organisms, it makes an attractive target for new therapeutics. Interfering with effective delivery of effectors could have substantial consequences on disease pathology and, therefore, it is important to understand how bacteria sense cell contact in order to activate the T3SS and how both the fidelity and kinetics of effector delivery is coordinated.

In the Yersinia, genes of the T3SS are located on a $70 \mathrm{~kb}$ virulence plasmid, and the expression of these genes in vitro is controlled primarily by temperature and calcium concentration, a phenomenon referred to as the low calcium response (LCR) (Sample et al., 1987; Mehigh et al., 1989; Michiels et al., 1990; Straley et al., 1993). At ambient temperature, T3SS genes are not expressed. However, upon transfer of Yersinia cultures from $26^{\circ} \mathrm{C}$ to $37^{\circ} \mathrm{C}$ in the presence of millimolar calcium, conditions representing the mammalian host, T3SS genes are expressed at low levels and the injectisome is built (Straley et al., 1993). Chelating calcium from the medium in vitro causes the bacteria to undergo growth cessation and triggers massive up-regulation of T3SS gene expression along with secretion of T3SS substrates, known

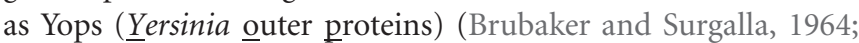
Straley and Bowmer, 1986; Michiels et al., 1990; Straley et al., 1993; Petterson et al., 1996). In vivo, cell contact triggers polarized translocation of effector Yops into host cells (Rosqvist et al., 1994; Persson et al., 1995; Petterson et al., 1996; Lee et al., 1998) and growth cessation is thought to be overcome by additional environmental signals (Fowler and Brubaker, 1994; Fowler et al., 2009).

This review will focus on several factors that regulate the T3SS from both the proximal end of the injectisome inside bacteria and the distal end inside host cells. The Yersinia T3SS is a wellcharacterized archetype for this method of protein translocation, therefore, the data presented here will be compiled primarily from the Yersinia species: Y. pestis and the two closely related enteric pathogens Y. pseudotuberculosis and Y. enterocolitica. We 
will briefly review the building of the injectisome before discussing in more detail the regulation of translocation. We focus on the roles of YopN and YopK, which have been shown to play roles in governing substrate specificity during translocation. In addition, YopK, YopE, and YopT have been shown to play a role in T3SS regulation after they are injected into host cells, and those activities will be discussed as well.

\section{THE MAKING OF AN INJECTISOME}

The "T3SS" or "injectisome" is homologous to the bacterial flagellum and is composed of several components that must be defined for the context of this review. YscC forms a ring in the bacterial outer membrane (the $\mathbf{O M}$ ring), and $\mathrm{YscD}$ and $\mathrm{YscJ}$ form a ring in the inner membrane (the MS ring). Together these proteins create a scaffold anchored within the peptidoglycan, and therefore, they will be referred to as scaffold proteins (Figure 1, purple). The basal body is the portion of the injectisome that spans the inner and outer membrane, including the scaffold proteins (YscCDJ) as well as proteins embedded within or connected to the scaffold: export apparatus (YscRSTUV Figure 1, orange), ATPase complex (YscNKL Figure 1, blue), and $\mathrm{C}$ ring (YscQ Figure 1, blue). The needle is the attached polymer of YscF that extends from the basal body into the extracellular milieu

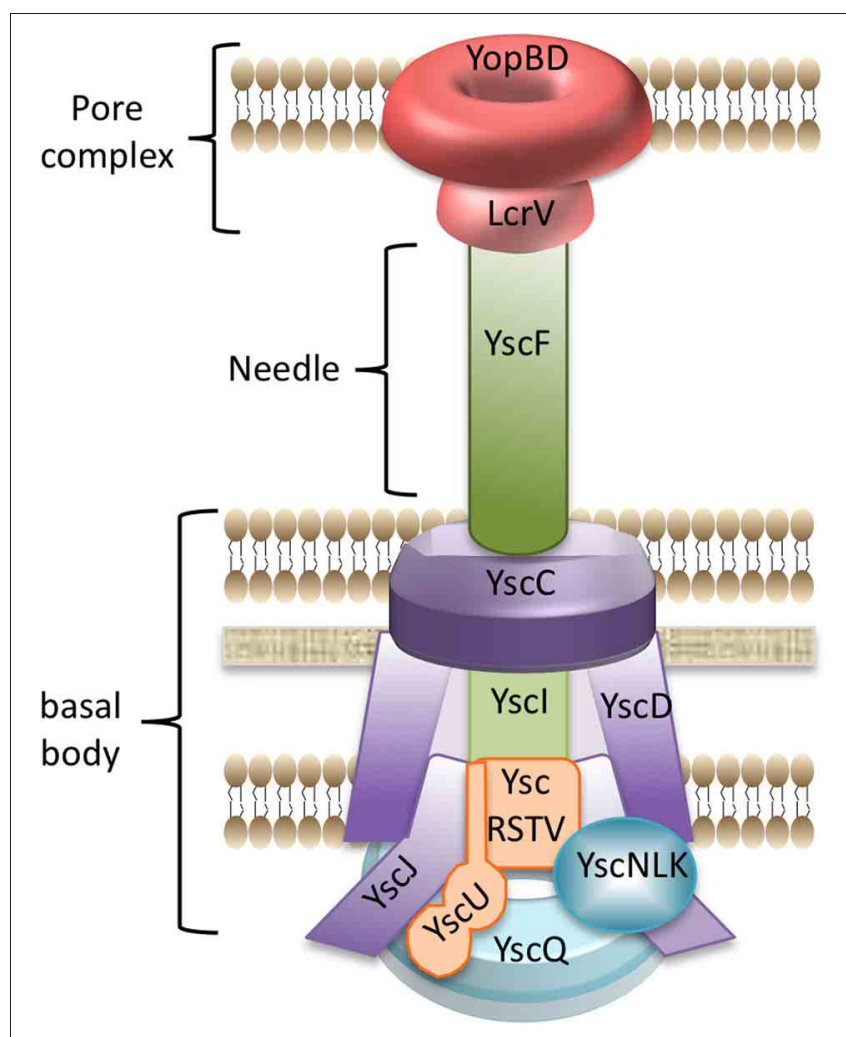

FIGURE 1 | Model of the injectisome. Shown is a cartoon depicting the structural components of the Yersinia injectisome. Purple, scaffold proteins: YscC, YscD, YscJ; Orange, export apparatus proteins: YscR, YscS, YscT, YscU, YscV; Blue, cytoplasmic components: YscQ (C-ring) and YscN, YscL, YscK (ATPase complex); Green, Yscl (rod) and YscF (needle); Red, pore complex: LcrV (needle tip complex) and YopB/YopD (translocation pore).
(Figure 1, green). Connecting the needle tip to the target host cell is a hypothetical structure called the pore complex (Figure 1, red), which is composed of LcrV at the needle tip and YopB/YopD forming a pore in the host cell membrane. The injectisome is the completed conduit comprised of the basal body, needle, and pore complex that allows translocation of Yops into host cells. Though a complete injectisome docked onto a host cell has never been observed, Figure 1 shows a model for how these components may be assembled.

\section{THE BASAL BODY}

The basal body formation begins with oligomerization of $\mathrm{YscC}$, which forms the OM ring that spans the outer membrane and extends into the periplasm (Koster et al., 1997; Diepold et al., 2010). This is in contrast with the basal body of the flagellum which begins its assembly in the inner membrane and builds outward (Erhardt et al., 2010). After the OM ring is formed, a ring of YscD is assembled in the inner membrane and is thought to connect the outer and inner membrane rings (Spreter et al., 2009; Diepold et al., 2010; Ross and Plano, 2011). YscD then recruits YscJ, which oligomerizes to complete the MS ring (Yip et al., 2005; Hodgkinson et al., 2009; Diepold et al., 2010). With the assembly of these structures, a basic channel through the bacterial envelope is formed, which serves as a base for assembly of the remaining injectisome components.

An ATPase complex composed of YscN, YscK, and YscL forms on the cytosolic face of the basal body. YscN is the ATPase necessary for the secretion of substrates by the T3SS. YscL is a negative regulator of ATPase activity, while the function of $\mathrm{YscK}$ is as yet unknown (Blaylock et al., 2006). It has, however, been suggested that YscK may bridge the ATPase complex to the $\mathrm{C}$ ring. YscQ is assumed to comprise the $\mathrm{C}$ ring in Yersinia injectisomes based on homology to flagellar components (Driks and DeRosier, 1990; Khan et al., 1992; Kubori et al., 1997; Young et al., 2003; Thomas et al., 2006), co-localization with YscC in the membrane (Diepold et al., 2010) and association with the ATPase complex (Jackson and Plano, 2000). The ATPase complex and C ring associate with the scaffold proteins forming a nearly complete basal body (Diepold et al., 2010).

In a separate pathway, the export apparatus, composed of integral membrane proteins YscRSTUV (Allaoui et al., 1994; Fields et al., 1994; Minamino et al., 1994; Minamino and Macnab, 2000; Creasey et al., 2003; Melen et al., 2003; Ghosh, 2004; Spreter et al., 2009; Berger et al., 2010), assembles within the inner membrane independently of the scaffold proteins (Diepold et al., 2011). YscRST are necessary to promote the oligomerization of YscV. At this point, the assembly pathways converge and the export apparatus is recruited to YscJ in the MS ring of the scaffold (Diepold et al., 2011). With the joining of the scaffold, ATPase complex and export apparatus, the basal body is complete and is now capabable of exporting secretion substrates.

\section{THE NEEDLE AND THE “EARLY” STAGE}

Upon completion of the basal body, proteins necessary for needle assembly can be exported. We refer to this point as the "early" stage, because only "early" substrates are translocated (Figure 2). These include the first proteins to be secreted: YscIFPXO and 


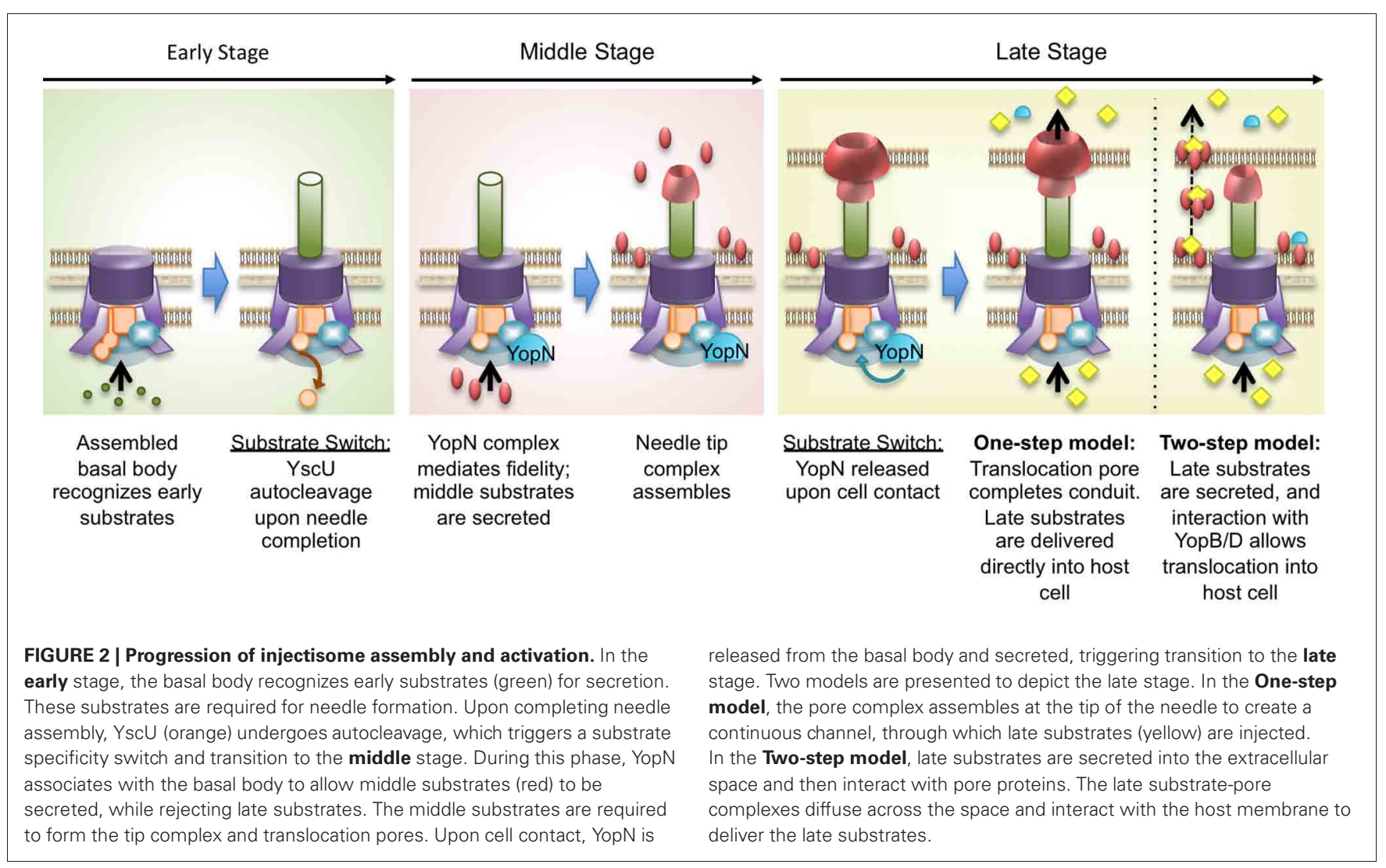

YopR (Payne and Straley, 1998, 1999; Day and Plano, 2000; Agrain et al., 2005b; Blaylock et al., 2010). YscI is suggested to form a rod that allows substrate passage across the inner membrane (Allaoui et al., 1995; Sukhan et al., 2003; Marlovits et al., 2004; Wood et al., 2008; Sal-Man et al., 2012). The needle protein YscF is then secreted through the YscI rod (Diepold et al., 2012). Polymerization of YscF polymerizes forms the needle, which extends $\sim 41 \mathrm{~nm}$ from the bacterium in $Y$. pestis or $\sim 58 \mathrm{~nm}$ in $Y$. enterocolitica. The needle has an outer diameter of $\sim 6-7 \mathrm{~nm}$ and an inner diameter of $\sim 2-3 \mathrm{~nm}$ (Kubori et al., 1998; Blocker et al., 2001; Hoiczyk and Blobel, 2001; Journet et al., 2003).

Another T3S substrate, YopR, is important in the early stages of needle assembly (Allaoui et al., 1995; Lee and Schneewind, 1999), though its precise role is unclear. A yopR mutant secretes YscF, but cannot form a polymerized YscF needle (Riordan et al., 2008; Blaylock et al., 2010). In addition, YopR was found to interact with the ATPase protein YscN (Sorg et al., 2006) suggesting that YopR might regulate either secretion or polymerization of YscF.

YscP participates in needle assembly by regulating needle length (Payne and Straley, 1999; Stainier et al., 2000; Journet et al., 2003; Agrain et al., 2005a; Mota et al., 2005) and is, therefore, often referred to as the "ruler" protein. In support of its role in regulating needle assembly, a $\Delta y s c P$ mutant over secretes $\mathrm{YscF}$ and forms needles of indiscriminate length, while secretion of "middle" or "late" substrates (pore complex components and Yop effectors) is severely compromised (Edqvist et al., 2003; Journet et al., 2003; Agrain et al., 2005a,b; Diepold et al., 2012).
YscX, YscY, and YscO are also required for export of early substrates, but their precise roles are unknown. Furthermore, though YscX and YscO are required for secretion of the early substrates, they do not appear to be secreted from the bacterium until needle assembly is complete (Payne and Straley, 1999; Day and Plano, 2000; Diepold et al., 2012). Some work has implicated YscO as a chaperone escort (Evans et al., 2006; Evans and Hughes, 2009; Ibuki et al., 2011), while data from Schneewind and colleagues suggest that $\mathrm{YscO}$ facilitates $\mathrm{YscP}$ interaction with the basal body during needle assembly (Riordan and Schneewind, 2008; Riordan et al., 2008). Therefore, YscO might assist YscP in regulating needle assembly, and afterward is exported. Both YscX and YscY associate with the export apparatus via YscV (Diepold et al., 2012), and YscY is thought to be the chaperone required for YscX secretion (Iriarte and Cornelis, 1999; Day and Plano, 2000). YscY has also been shown to bind to $\mathrm{SycD}$, which is a chaperone facilitating secretion of the middle substrates YopB and YopD. The YscY-SycD interaction suggests a possible role for YscY in regulating secretion specificity (Broms et al., 2005). It is possible that once the needle is assembled, YscY releases YscX for secretion, and then YscY assists in secretion of the middle substrates that are required for the next stage of injectisome assembly.

In addition to its role in regulating needle length, YscP also interacts with $\mathrm{YscU}$ in the export apparatus to mediate a substrate specificity switch (Figure 2). Once the needle has reached the appropriate length, the switch is triggered, allowing recognition of middle and late T3SS substrates (YopBD and effector Yops, respectively). YscU has both a membrane spanning domain that 
anchors it in the inner membrane and a large cytosolic domain that is essential for substrate specificity (Allaoui et al., 1994; Edqvist et al., 2003; Sorg et al., 2007). It is thought that a conserved substrate specificity switch domain at the C-terminus of YscP interacts with the cytosolic domain of $\mathrm{YscU}$ to trigger autocleavage of YscU (Lavander et al., 2003; Agrain et al., 2005b; Sorg et al., 2007). This autocleavage is an essential step in the progression from the "early" to the "middle" stage. $y s c U$ mutants that cannot undergo proteolysis have severe consequences on expression and secretion of middle and late Yops and are also defective in preventing Yop secretion under restrictive conditions (+ calcium) (Riordan and Schneewind, 2008; Bjornfot et al., 2009).

\section{THE CALCIUM BLOCKADE}

After the needle is built, and YscU undergoes proteolytic cleavage, the T3SS is capable of secreting middle and late substrates: middle substrates are those comprising the pore complex, while late substrates are the effectors that are delivered into host cells. However, in medium containing calcium (or in the absence of cell contact), secretion of late substrates is largely prevented due to the action of the YopN-TyeA-YscB-SycN complex, also referred to as the calcium plug (Yother and Goguen, 1985; Forsberg et al., 1991). During growth of wild type Yersinia in calcium-replete medium, secretion of early and middle T3SS substrates into the extracellular milieu is readily observed, whereas the late Yops are not released in large amounts until either calcium chelation or contact with a host cell occurs (Lee et al., 1998). Therefore, we use "middle" stage to refer to the T3SS after the completion of needle assembly and the YscP-YscU substrate switch has been triggered, but before contact with a host cell has been made (Figure 2).

Support for the "calcium block" model stems from observations that deletion of any of the YopN-TyeA-YscB-SycN complex genes results in the massive secretion of both middle and late Yops in both the presence and absence of calcium in vitro, a defect known as a calcium blind phenotype (Forsberg et al., 1991; Skrzypek and Straley, 1995; Day and Plano, 1998; Iriarte et al., 1998; Jackson et al., 1998; Cheng and Schneewind, 2000; Cheng et al., 2001; Sundberg and Forsberg, 2003). During infection of tissue culture cells, this defect manifests as a loss of specificity phenotype whereby Yops are secreted into the medium as well as translocated into host cells (Boland et al., 1996; Lee et al., 1998; Cheng and Schneewind, 2000; Cheng et al., 2001; Day et al., 2003). TyeA binds to the C-terminal half of YopN and acts as a negative regulator of YopN secretion, helping to maintain a secretion incompetent state in the presence of calcium (Iriarte et al., 1998; Cheng et al., 2001; Ferracci et al., 2004, 2005; Schubot et al., 2005). YscB and SycN bind to each other in the bacterial cytosol and then to an N-terminal region of YopN (Day and Plano, 1998; Cheng et al., 2001). To release the YopN-TyeA block once cell contact is made, YscB and SycN act as chaperones to mediate YopN export through the injectisome.

\section{THE “MIDDLE" STAGE AND TRANSLOCON ASSEMBLY}

The "middle" stage is distinguished by the secretion of the translocators (or "middle" Yops), which include LcrV, YopB, and YopD. These proteins are secreted into the extracellular milieu during tissue culture infection and during in vitro growth in calcium-replete medium (Lee et al., 1998; Cheng and Schneewind, 2000; DeBord et al., 2001; Houppert et al., 2012), indicating that they are secreted prior to cell contact. LcrV is secreted and polymerizes at the distal end of the YscF needle forming a pentameric needle tip complex (Mueller et al., 2005) that is necessary for translocation of late substrates (Goure et al., 2004, 2005). The pore proteins, YopD and YopB, contain one and two transmembrane domains, respectively, and are capable of inserting themselves into the host cell membrane (Hakansson et al., 1993; Rosqvist et al., 1995; Hakansson et al., 1996; Neyt and Cornelis, 1999; Montagner et al., 2011). The LcrV tip complex is thought to act as a platform for insertion of YopB and YopD into the host cell membrane (Goure et al., 2004, 2005; Picking et al., 2005; Broz et al., 2007; Mueller et al., 2008), and it is through this pore complex that late Yops are thought to be delivered. The properties and proposed functions of the pore complex proteins have been recently reviewed (Mattei et al., 2011).

Though a complete conduit between the needle and the host cell has never been observed, there is evidence from Yersinia and Shigella studies to support the idea of a translocator complex that connects the needle with the host membrane. First, the YopB/YopD translocators (IpaB/IpaC in Shigella) can be isolated from host membranes, and LcrV (IpaD in Shigella) is required for insertion of YopB/YopD (IpaB/IpaC) (Goure et al., 2004, 2005; Picking et al., 2005; Broz et al., 2007). Second, IpaB has been observed on the tip of needles as part of the tip complex (Ide et al., 2001; Olive et al., 2007; Veenendaal et al., 2007). Most recently, YopD has been detected in purified needle preparations in an LcrV-dependent manner (Ligtenberg et al., 2012). Furthermore, there is a direct correlation between the length of the needle, the distance between the bacteria and host cell, and the ability to inject Yops: the effect of changing the length of the surface adhesin YadA on Y. enterocolitica can be counteracted by changing the length of the needle (Mota et al., 2005). In our schematic (Figure 2, One-step model), assembly of the translocation pore complex at the distal end of the needle would form a complete channel connecting the bacterium to the host cell, and this would trigger the "cell contact signal" that releases the YopN regulatory blockade. This signifies transition to the "late" stage, whereby the "late" Yops (effectors) are now delivered directly into host cells.

For many years, T3SS models have depicted pore complex formation as the final step in completing a channel between the bacterium and the host cell (Figure 2, One-step model). However, this hypothetical model has been recently challenged by the demonstration that extracellular late Yops, in association with YopB and YopD, could be translocated into host cells (Akopyan et al., 2011; Edgren et al., 2012) (Figure 2, two-step model). Akopyan and colleagues found that middle and late Yops were present on the surface of $Y$. pseudotuberculosis cells in calciumreplete medium, indicating that bacteria are coated with Yops prior to host cell contact (Akopyan et al., 2011; Edgren et al., 2012). This is in contrast to prior work showing that late Yops were not secreted into the medium prior to cell contact (Rosqvist et al., 1994; Sory and Cornelis, 1994; Persson et al., 1995; Lee et al., 1998; Cheng and Schneewind, 2000; DeBord et al., 2001). Although the observations do not rule out the one-step "conduit" model of translocation, they do suggest that late Yops can also be 
delivered into host cells by a two-step method with an extracellular intermediate step. It is possible that while middle Yops are secreted in readily detected amounts prior to cell contact, there is "leaky" low level secretion of late Yops, that are able to aggregate onto the bacterial surface and associate with YopB/D translocators. Upon cell contact (or calcium depletion) the YopN blockade is released and massive amounts of late Yops are then exported and are readily detected. Notably, the two models are not mutually exclusive, and in both models, YopB and YopD are required for late Yop delivery.

\section{TRANSITION TO THE “LATE” STAGE}

There is an abundance of data to support a model in which there is a conformational change in the needle that is triggered by external stimuli such as cell contact or calcium depletion. This change would be transduced to the basal body, which then triggers release of the TyeA/YopN complex and subsequent translocation of YopN, thereby relieving its blockade on late Yop export (Ferracci et al., 2004, 2005; Torruellas et al., 2005; Hamad and Nilles, 2007; Davis et al., 2010). In support of this model, a crystal structure of the YopN/TyeA complex revealed that TyeA has a conserved C-terminal helix that could potentially interact with components of the basal body (Schubot et al., 2005). Additionally, a YopN-TyeA hybrid fusion protein expressed in $Y$. pestis is completely functional for calcium sensing and Yop secretion regulation (Ferracci et al., 2004). This suggests that YopN binding of TyeA in itself does not block the injectisome; rather that TyeA tethering of YopN to the basal body causes the blockage. In further support of this, YopN mutants that constitutively block secretion require the presence of TyeA, but not chaperones YscB or SycN (Ferracci et al., 2005). This would be consistent with a conformation change in the T3SS that releases TyeA, thereby relieving the late Yop secretion block. Previous work investigating needle protein $\mathrm{YscF}$ has shown that the needle itself also can act as a calcium sensor, since mutations can be isolated that correlate with different stages of regulation (Torruellas et al., 2005; Davis et al., 2010). Therefore, contact with a host cell could trigger a cascade of conformational changes throughout the T3SS such that the information is transduced through the needle and down to the basal body. Upon receiving the signal, the TyeA tether is broken, which allows delivery of YopN into host cells to relieve the block on late Yop secretion.

\section{REGULATORS OF INJECTION: YopK, YopE, AND YopT YOPK: A REGULATOR OF TRANSLOCATION RATE}

YopK was first discovered in Y. pestis by Straley and Bowmer in a screen searching for LCR genes (Straley and Bowmer, 1986). It was later determined that YopK (named YopQ in Y. enterocolitica) is present in all three pathogenic Yersinia spp. with a high degree of sequence homology (Fernandez-Lago et al., 1994; Holmstrom et al., 1995a). YopK is a T3SS substrate and has an $\mathrm{N}$-terminal secretion signal within the first 10 residues (Michiels and Cornelis, 1991; Anderson and Schneewind, 1999), and expression of YopK is regulated by calcium and temperature as are other effector Yops (Straley and Bowmer, 1986; Holmstrom et al., 1995a). YopK was found to be important for the mouse model of $Y$. pestis infection as a $\Delta y o p K$ mutant is severely attenuated compared to wild type (Straley and Bowmer, 1986; Straley and Cibull, 1989; Holmstrom et al., 1995a). The $\Delta y o p K$ mutant poorly colonizes the liver and is quickly cleared from the spleen (Straley and Cibull, 1989). Likewise, the Y. pseudotuberculosis $\triangle y o p K$ mutant colonizes Peyer's patches, but due to rapid clearance cannot colonize the spleen (Holmstrom et al., 1995a,b). YopK has no known enzymatic activity, and the yopK mutant retains the ability to cause cytotoxicity and prevent phagocytosis (Holmstrom et al., 1995a,b).

Understanding the role of YopK during infection was a challenge since it is expressed at low levels. Attempts to visualize YopK during infection by immunofluorescence only showed a YopK signal within bacteria near the zone of contact with the host cell (Holmstrom et al., 1995a,b, 1997). Differential detergent fractionation was also unable to accurately decipher YopK localization as it is found in the digitonin pellet fraction containing adherent bacteria, along with host cell membranes and organelles (Lee and Schneewind, 1999). With the creation of a GSK tag reporter system, Garcia et al. finally demonstrated that YopK from $Y$. pestis is injected into host cells during infection (Garcia et al., 2006). Y. pseudotuberculosis YopK translocation was also observed recently using a $\beta$-lactamase (Bla) reporter (Thorslund et al., 2011). Because YopK is expressed at low levels in comparison to other Yops (Holmstrom et al., 1995a) it may be that the amount of YopK delivered to host cells is below the limit of detection by previous methods.

Early work found that a $Y$. pseudotuberculosis yopK mutant infection induced cytotoxicity (seen as cell rounding) in host cells more rapidly than wild type, while overexpression of YopK resulted in a lack of cytotoxicity (Holmstrom et al., 1997). This phenotype led researchers to investigate the possibility that YopK is involved in the regulation of translocation. Immunofluorescence microscopy on infected culture cells revealed that a $Y$. pseudotuberculosis yopK mutant injects a larger quantity of YopE and YopH into host cells, whereas overexpression of YopK inhibits translocation of YopE and YopH (Holmstrom et al., 1997). This suggests that the hypercytotoxicity phenotype of a yopK mutant is due to an increased concentration of YopE, a GTPase activating protein (GAP), in host cells (Holmstrom et al., 1997; Aili et al., 2002). It was found that YopK has no role in transcription or expression of effectors YopE or YopH, supporting the hypothesis that YopK activity is restricted to regulating translocation (Holmstrom et al., 1997).

\section{Indirect measurements of translocation regulation}

Shortly before the characterization of YopK by Holmstrom and colleagues, a contact-hemolytic assay, previously utilized for poreforming toxins (Sansonetti et al., 1986), was modified to assess the membrane disrupting ability of Yersinia translocator protein YopB (Hakansson et al., 1996). In this assay, red blood cells are infected with Yersinia strains and the subsequent release of hemoglobin provides a metric for pore formation. In addition, differentially sized sugars were incubated with infected RBCs to estimate the size of lytic membrane pores formed during infection (Bhakdi et al., 1986; Braun et al., 1987). It was shown using [ $\left.\mathrm{C}^{14}\right]$ sucrose that an influx of sugar into host cells occurs upon effectorinduced membrane disruption and that the influx can be blocked 
by incubation with sugar moieties larger than the membrane pore (Bhakdi et al., 1986; Braun et al., 1987). Because mutations in yopK (as well as yopE discussed below) gave rise to higher levels of effector translocation, it was hypothesized that the phenotype may be related to a change in translocation pore size. As a result, several studies were undertaken to investigate this possibility.

Using the contact-hemolysis assay, Holmstrom and colleagues found that a $Y$. pseudotuberculosis $\Delta y o p K$ mutant showed a significant increase in hemoglobin release compared to wild type infection of erythrocytes and that hemolysis was dependent on the presence of YopB (Holmstrom et al., 1997). Complementation of YopK restored wild type levels of hemoglobin release, and overexpression of YopK also rescued the hemolytic phenotype of a multi-Yop mutant (Holmstrom et al., 1997). Incubation of infected erythrocytes with differentially sized sugars indicated a wild type pore size of $2.2 \mathrm{~nm}$, an increased pore size of $3.5 \mathrm{~nm}$ in the absence of YopK, and a decreased pore size of $>1.2 \mathrm{~nm}$ when YopK was overexpressed (Holmstrom et al., 1997). While these lytic assays do not directly measure translocation of Yops, they do suggest that YopK can control translocation pore size, which can in turn have an effect on translocation.

Lactate dehydrogenase (LDH) release is a common cytotoxicity assay that is often used to measure membrane disruption and/or cell death by detecting the concentration of cytosolic LDH that is released into the extracellular medium. Several groups have used this assay to test lytic pore formation as correlate of translocation regulation. In contrast to the contact-hemolysis assay, the $\triangle y o p K$ mutant had no effect on LDH release from HeLa cells or bone marrow derived macrophages during Y. pseudotuberculosis infection (Aili et al., 2008). This discrepancy could be due to differences between nucleated and non-nucleated cells, or it could reflect differences in cytoskeletal networks and actin remodeling in various cell types.

It is not yet clear how the observed changes in "pore" size (as determined by lytic pore formation assays) correlate with changes in translocation levels. If the translocation pore is indeed larger, then is the internal diameter of the needle larger to accommodate increased flow of effectors? Considering prevailing models in which the translocation pore complex is connected to the basal body through the needle, a change in the pore should trigger compensatory changes throughout the injectisome. Another possibility is that the assays which measure pore formation do not directly measure the pores that are actively translocating, and instead, the results could simply reflect an altered conformation that is perhaps less stable or more flexible, and therefore appears larger. If the pore size is not physically larger, it may be that the altered conformation of the pore, and by extension the rest of the injectisome, triggers a change in the export apparatus and/or ATPase complex such that secretion substrates are recognized and initiated through the channel at a faster rate.

\section{Direct measurement of translocation regulation}

To better understand the mechanism by which YopK regulates translocation, a time course infection was performed using a Bla reporter system (Dewoody et al., 2011). This approach relies on detection of Bla reporter fused to an effector Yop, which is injected into host cells in a T3SS-dependent manner (Marketon et al.,
2005; Dewoody et al., 2011). Using a fluorescent Bla substrate, translocation of the Yop-Bla reporter can be detected quantitatively by flow cytometry, thus providing a direct measure of translocation. When infections are synchronized, this approach also affords a comparison of translocation efficiency or rate by different strains. Measuring translocation rates with a YopM-Bla reporter revealed that wild type $Y$. pestis and a $\Delta y o p K$ mutant initiate injection with similar efficiency (Dewoody et al., 2011). However, a difference in translocation between the two strains can be seen as soon as $1.5 \mathrm{~h}$ post-infection, showing that both strains inject the same number of cells, but the $\Delta y o p K$ strain injects more YopM-Bla reporter per cell and does so at a faster rate (Dewoody et al., 2011).

Observing that YopK is translocated into host cells and also plays a prominent role in controlling the injection of other effectors prompted the question of whether YopK performs this regulatory function within the attached bacterium or within target cells. Injection of YopK into host cells is essential to its ability to regulate translocation of effector Yops because a non-injectable form of YopK (Gst-YopK) does not complement a $\Delta y o p K$ mutant (Dewoody et al., 2011). In addition, YopK expressed solely in the host cell can restore regulation of injection during infection with a $\Delta y o p K$ mutant (Dewoody et al., 2011). Taken together, these data suggest that YopK is injected into host cells, and then acts as a strong down-regulator of translocation by transmitting a signal back to the bacterium to slow translocation.

\section{YopK protein-protein interactions}

Given that YopK works within target cells to regulate translocation, along with the evidence suggesting that it affects pore size or conformation, researchers began investigating whether YopK interacts directly with the translocation pore complex. It was shown that YopK could be immunoprecipitated with YopB from cells infected with $Y$. pseudotuberculosis, providing the first evidence of a direct interaction between YopK and the pore (Brodsky et al., 2010). In another study, infection of erythrocytes with Y. pseudotuberculosis resulted in YopK, YopB, and YopD being pulled down from red blood cell membranes, suggesting that they form a complex in target cell membranes (Thorslund et al., 2011). In the same study, YopK interacted with His-tagged YopD from bacterial supernatants, but seemingly not YopB (Thorslund et al., 2011). Recent data regarding Y. pestis YopK is in agreement with the Y. pseudotuberculosis data (Dewoody et al., 2012). In this study, YopK was expressed from a eukaryotic expression vector within host cells and then infected with a $Y$. pestis $\Delta y o p K$ mutant. The infected cells were then lysed, and YopK along with any interacting proteins were co-immunoprecipitated with affinity purified YopK antibody. YopK, which was only present within host cells, was able to pull down YopD but not YopB (Dewoody et al., 2012). Collectively, these data support a model for YopK interacting directly with YopD of the translocation pore within the cytosol of targeted cells thereby influencing the function of the injectisome.

\section{YopK regulates translocation fidelity}

Control of substrate fidelity from within the bacteria by YopN has been known for quite some time (Brubaker and Surgalla, 1964; 
Michiels et al., 1990; Rosqvist et al., 1994; Persson et al., 1995; Boland et al., 1996; Day and Plano, 1998; Cheng and Schneewind, 2000; Cheng et al., 2001). A $\Delta y o p N$ mutant aberrantly secretes and injects both middle and late Yops during infection (Boland et al., 1996; Cheng and Schneewind, 2000). Recent work in our lab has revealed a similar but distinct phenotype for the $Y$. pestis $\Delta y o p K$ mutant (Dewoody et al., 2012). These studies build upon an earlier observation that showed, using immunofluorescence, that the middle substrate, YopD, is injected into host cells by a yopK mutant (Francis and Wolf-Watz, 1998). By fractionating infected cells and immunoblotting for a series of Yops representing early, middle, and late T3SS substrates, we found that both middle (LcrV, YopD, and YopB) and late (YopE, YopH, YopM, and YopN) Yops are injected into host cells, while normal rejection of early substrates (YopR and YscF) is maintained. This observation was confirmed through the use of middle Yop reporters, which were created by fusing Bla to YopD and YopB. We found that YopD-Bla and YopB-Bla are injected by the yopK mutant, but not by wild type or the yopE mutant (Dewoody et al., 2012), which is in agreement to previous work (Francis and Wolf-Watz, 1998). Thus, it appears that like YopN, YopK is also required to maintain fidelity of translocation such that only late Yops are delivered into host cells.

The phenotype of a yopK mutant injecting middle substrates into host cells is quite novel and indicates that YopK is a bifunctional protein capable of regulating fidelity as well as rate of Yop injection. Importantly these properties of YopK are distinct and genetically separable, since a point mutation (YopK $\mathrm{D}_{\mathrm{D} 6 \mathrm{~A}}$ ) abolishes the ability of YopK to control the rate of late Yop delivery but is still able to inhibit injection of middle Yops (Dewoody et al., 2012). Notably, though the YopK $K_{D 46 A}$ mutant is not able to regulate late Yop injection, it is still able to associate with YopD and therefore presumably maintains an interaction with the translocation pore (Thorslund et al., 2011; Dewoody et al., 2012). Furthermore, although expression of YopK within host cells can complement the yopK mutant in trans, by lowering the injection levels of late Yops, it cannot prevent injection of middle Yops. Together these data indicate that the two functions of YopK are genetically and spatially distinct. We currently favor a model in which YopK interacts with the basal body during the "late" stage in order to ensure that only late Yops travel through the injectisome (Figure 3A).

As YopK is itself injected at low levels into host cells, its appearance within the host cytosol and localization to the translocation pore could provide a negative feedback signal to down-regulate further effector delivery (Figure 3B). Why provide such a negative feedback signal? Perhaps this would provide an external cue to initiate detachment from the host cell, which could facilitate dissemination and subsequent re-colonization in vivo. Additionally, it would be prudent to prevent over-injection of cytotoxic effectors, since that would likely cause an early inflammatory response, which could be counterproductive to disease progression. In support of this, yopK mutants are known to have colonization and dissemination defects (Straley and Bowmer, 1986; Straley and Cibull, 1989; Holmstrom et al., 1995a,b). Furthermore, a Y. pseudotuberculosis yopK mutant triggers caspase-1 and inflammasome activation (Brodsky et al., 2010), while a Y. pestis yopK mutant

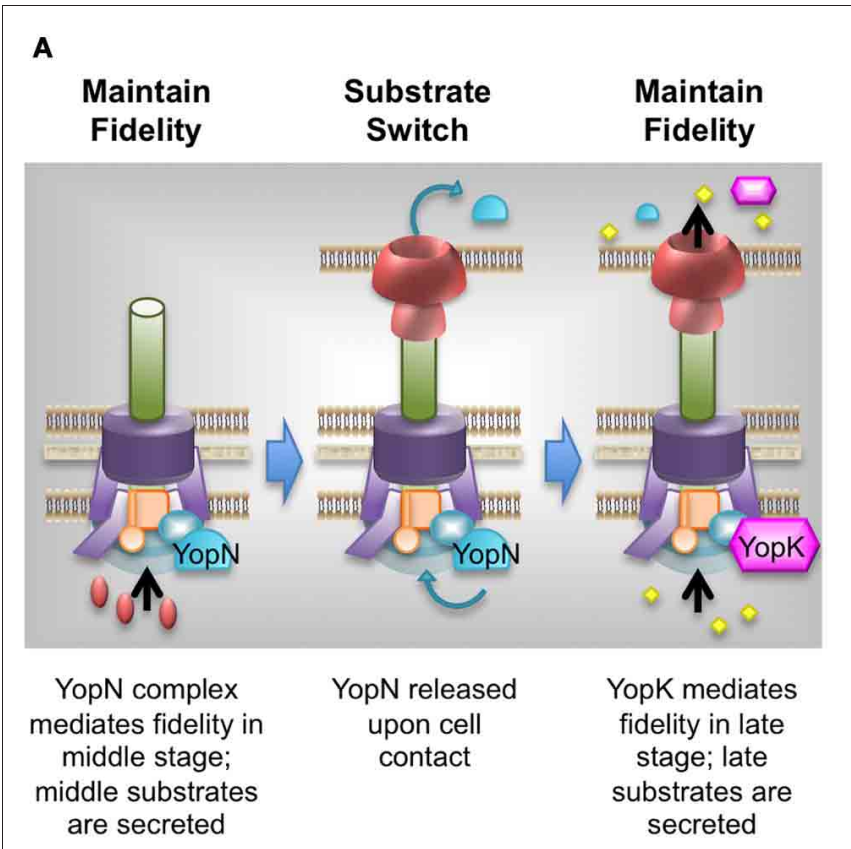

B

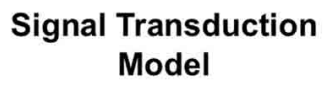

\section{Plug Model}
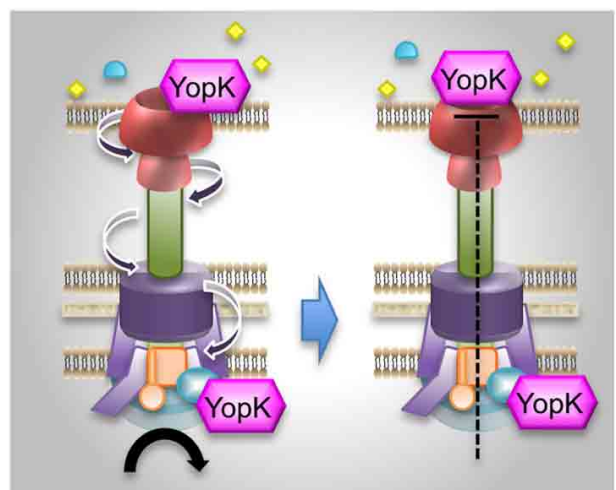

YopK binds to pore and triggers cascade of conformation changes that inhibit further injection

FIGURE 3 | Models for YopK functions. (A) Controlling fidelity. During the middle stage, YopN is associated with the basal body to prevent premature release of late substrates. This blockade is released upon cell contact by translocating YopN into host cells. YopK now associates with the basal body to prevent aberrant injection of middle substrates. (B) An OFF switch. During the late stage, YopK is injected into the host cell and acts to down-regulate injection of the other late substrates. Two models are shown to depict how this may happen. In the Signal transduction model, YopK would interact with the pore complex and cause a conformational change in the pore, which then triggers structural changes along the length of the injectisome to provide a signal to the basal body. Further transport of late substrates is then inhibited. In the Plug model, such structural changes are not necessarily induced. Rather, YopK binding to the pore causes a physical blockade to the channel such that substrates cannot pass through the pore. 
causes increased apoptosis and death of alveolar macrophages (Peters and Anderson, 2012).

How might YopK down-regulate late Yop injection? We envision two basic options for YopK activity within host cells: (1) YopK binds to the translocation pore to trigger conformational changes that influence substrate recognition and/or transport by the basal body (Figure 3B, signal transduction model), (2) YopK binds to the translocation pore and acts as a plug to block the channel and prevent further late Yop translocation (Figure 3B, plug model). If YopK acts as a plug, then one would predict that mutations abolishing YopK function would also abolish YopK binding to the pore proteins. The combined observations that YopK can bind to the translocation pore component YopD, and that the YopK $K_{\mathrm{D} 46 \mathrm{~A}}$ mutant loses the ability to control late Yop injection without losing its association with YopD, suggest that YopK binding to YopD might create a structural change in the pore complex that is transduced to the bacterial side of the injectisome. Much more work is necessary to understand how YopK performs its two regulatory functions, and in doing so, it may be possible to determine whether an analogous regulator exists in other organisms.

\section{YopE: THE GTPase ACTIVATING PROTEIN}

YopE is one of the best characterized of the effector Yops, perhaps because it is one of the most highly translocated into host cells and is essential to virulence (Straley and Cibull, 1989; Lee et al., 1998). YopE is highly cytotoxic as seen by a characteristic cell rounding as soon as 15 minutes post-infection (Straley and Cibull, 1989; Rosqvist et al., 1991). Cell rounding is caused by disruption of the host cell cytoskeleton, in particular the actin microfilaments in stress fibers (Rosqvist et al., 1991). In addition to causing cell rounding, the actions of YopE on the cytoskeleton also serve to immobilize the cells and prevent phagocytosis. YopE acts as a GAP by maintaining specific GTPases in an inactive, or GTP-hydrolyzed, state using the conserved arginine finger motif associated with such domains (Black and Bliska, 2000; Von Pawel-Rammingen et al., 2000). Small Rho GTPases RhoA, Rac1, and Cdc42 are inactivated by YopE in vitro, although $\mathrm{Cdc} 42$ does not seem to be a target in vivo (Black and Bliska, 2000; Aili et al., 2006). During infection, the cytosolic pool of activated RhoG and Racl is quickly depleted when infected with Y. pseudotuberculosis expressing YopE (Wong and Isberg, 2005; Mohammadi and Isberg, 2009). In addition to its anti-phagocytosis role, YopE is also implicated in controlling pore formation and regulating translocation, and these are all thought to involve actin regulation. Each topic is addressed below.

\section{Anti-phagocytosis}

YopE plays several roles in the host cell in addition to (or due to) actin regulation. Because yersinae proliferate extracellularly, it is essential to block phagocytosis after contact with host cells. Y. pseudotuberculosis YopE was shown to play a role in preventing engulfment by macrophages (Rosqvist et al., 1990). To assess the role of GAP activity in phagocytosis, a mutation of the essential arginine residue (YopE $E_{\mathrm{R} 144 \mathrm{~A}}$ ) was evaluated. Although YopE $_{\mathrm{R} 144 \mathrm{~A}}$ was translocated efficiently, it could not prevent phagocytosis by
HeLa cells (Black and Bliska, 2000). This indicates that YopE's GAP activity is essential for its anti-phagocytic activity.

\section{Inhibition of lytic pore formation}

Another facet of YopE's function is the ability to inhibit the formation of lytic pores. Several groups have shown that infection with a $Y$. pseudotuberculosis $\triangle$ yopE mutant released more LDH from HeLa cells than did a wild type infection, and that the phenotype was dependent on the GAP domain of YopE (Viboud and Bliska, 2001; Aili et al., 2006, 2008; Viboud et al., 2006; Mejia et al., 2008). In contrast to $\mathrm{LDH}$ release assays, a contact-hemolysis assay showed $Y$. pseudotuberculosis $\Delta y o p E$ caused hemoglobin release similar to wild type infection (Holmstrom et al., 1997). Interestingly, as noted above the same assays performed on yopK mutants also yielded contrasting results, but in the case of $y o p K$, it was the hemolysis assay that showed a phenotype. The difference in phenotypes may be related to differences in the cytoskeleton of each cell type, as RBCs and epithelial cells have different actin cytoskeletal networks (Nans et al., 2011). These observations support the idea that YopE and YopK work by different mechanisms within host cells to control translocation pores.

To further analyze the role of YopE GAP activity in lytic pore formation, Viboud et al. transfected HeLa cells with constitutively active forms of RhoA or Racl that cannot hydrolyze bound GTP. When HeLa cells were transfected with activated GTPases before infection, ectopic expression of YopE could no longer complement the yopE mutant and resulted in high $\mathrm{LDH}$ release (Viboud and Bliska, 2001). Thus, constitutively active GTPases in the host cell blocked the ability of YopE to function. Additionally, actin regulation was found to be important for the lytic pore inhibition, since the presence of actin polymerization inhibitors cytochalasin D and latrunculin B blocked $\mathrm{LDH}$ release during infection with the $\triangle y o p E$ mutant (Viboud and Bliska, 2001). Similar results were found with Clostridium difficile ToxB, an inhibitor of Rho, Rac, and Cdc42 GTPases (Mejia et al., 2008). Taken together, these data suggest that deactivation of small GTPases and disruption of host cell actin are essential to the mechanism by which YopE blocks lytic pore formation in host cell membranes.

\section{Translocation regulation}

$\triangle y o p E$ mutant strains have been shown to over-inject Yops into host cells during infection. Fractionation of infected cells has shown that a $Y$. pseudotuberculosis $\triangle y o p E$ mutant injects higher levels of YopH, and the corresponding YopER144A GAP mutant over-injects both YopH and YopE, (Aili et al., 2006, 2008; Isaksson et al., 2009). In Y. pestis, YopE was shown to regulate translocation using the YopM-Bla reporter (Dewoody et al., 2011). A $\Delta y o p E$ mutant showed an approximately 50\% increase in YopM-Bla injection compared to infection with wild type. This phenotype is dependent on YopE's GAP ability as ectopic expression of $Y_{\mathrm{R}} \mathrm{E}_{\mathrm{R} 144 \mathrm{~A}}$ could not complement the $\triangle y o p E$ parent strain (Dewoody et al., 2011).

In summary, YopE plays a role in three major aspects of Yersinia infection: anti-phagocytosis, repression of lytic pore formation, and translocation regulation. Each of these processes depends on small Rho GTPase deactivation and thus inhibition of 
actin polymerization. What has yet to be determined is whether one of these roles is the major function of YopE or if each is essential for infection. Furthermore, since there is no evidence for YopE binding directly to the translocation pore complex, any affect it has on the injectisome pore and translocation must be indirect. Finally, direct evidence for connections between YopE, the actin cytoskeleton, and changes to the injectisome have yet to be revealed.

\section{YopT: THE CYSTEINE PROTEASE}

YopT was first discovered in Y. enterocolitica as an effector that was translocated into host cells where it disrupted actin stress fiber and caused cytotoxicity (Iriarte and Cornelis, 1998). It is expressed in most $Y$. enterocolitica and $Y$. pestis strains, but only a portion of Y. pseudotuberculosis strains (Viboud and Bliska, 2001; Aepfelbacher, 2004; Viboud et al., 2006). YopT is dispensable for infection of Peyer's patches by Y. enterocolitica, and a $\Delta y o p T$ mutant shows a slight increase in virulence (Iriarte and Cornelis, 1998; Trulzsch et al., 2004). YopT is not necessary for Y. pseudotuberculosis infection, but can partially restore the virulence of a $\triangle y o p E$ mutant, suggesting some degree of redundancy between the two cytotoxins (Viboud et al., 2006). This redundancy may reflect the fact that both proteins target small Rho GTPases for inactivation, albeit through different methods. Though no direct role for YopT in translocation has been shown, its activity on the host cytoskeleton suggests that, like YopE, it contributes to the regulation of Yop injection.

\section{Anti-phagocytosis and lytic pore inhibition}

YopT is a cysteine protease and shares the conserved invariant $\mathrm{C} / \mathrm{H} / \mathrm{D}$ residues necessary for proteolytic function (Shao et al., 2002). During infection, YopT cleaves the prenyl modifications of membrane-bound RhoA, RhoG, Rac, and Cdc42. Proteolysis releases the GTPases from the membrane thereby disrupting actin structures such as stress fibers and phagocytic cups (Iriarte and Cornelis, 1998; Zumbihl et al., 1999; Grosdent et al., 2002; Aepfelbacher et al., 2003). Infections with Y. enterocolitica strains expressing YopT have shown that activated RhoA is released from the host membrane (Zumbihl et al., 1999; Sorg et al., 2001). Therefore, like YopE, YopT functions to disrupt actin regulation. In addition, YopT creates a pool of activated GTPases located in the nucleus (Shao et al., 2002, 2003; Aepfelbacher et al., 2003; Wong and Isberg, 2005; Mohammadi and Isberg, 2009). The significance of this during infection is unknown; however, it cannot be essential, as yopT mutants do not have a virulence defect in vivo (Iriarte and Cornelis, 1998; Trulzsch et al., 2004; Viboud et al., 2006).

Due to its ability to regulate host actin regulation, it is not surprising that YopT has a role in preventing phagocytosis and lytic pore formation. Expression of Y. pseudotuberculosis YopT alone is able to significantly reduce $\mathrm{LDH}$ release and lytic pore formation of infected HeLa cells (Viboud et al., 2006). YopT is also able to rescue the $\mathrm{LDH}$ release phenotype of a $\triangle y o p E$ mutant, but not when activated Rho or Rac are expressed in host cells (Viboud and Bliska, 2001). This indicates that while YopT and YopE function by distinct mechanisms, there is overlap of the resultant actin regulation phenotypes.
Inhibition of phagocytosis by YopT was measured using both a gentamicin protection assay and double immunofluorescence staining. Expression of YopT in a $\triangle y o p E H J T$ Y. pseudotuberculosis background resulted in a small decrease in phagocytosis when expressed at native levels and larger inhibition when overexpressed (Viboud et al., 2006). In either case, the anti-phagocytic effect of YopT was not as potent as that of YopE (Viboud et al., 2006). Interestingly, infection of macrophage lines with a $Y$. enterocolitica $\triangle y o p T$ mutant resulted in phagocytosis well above that of wild type and not significantly different from a $\Delta y o p E$ mutant (Grosdent et al., 2002). In fact, when bacteria were opsonized before infection, the $\triangle y o p E$ mutant had no affect on phagocytosis while the $\Delta y o p T$ mutant showed significantly more internalization (Grosdent et al., 2002). The reasons for the differences in observed phenotypes are not entirely clear; however, as with observations regarding pore formation with yopK and yopE mutants, the host background plays a confounding role in the functions of these proteins. Given that different eukaryotic cell types lead to different phenotypes for these mutants, future work may be able to utilize this knowledge to gain insight into the underlying mechanisms.

\section{PERSPECTIVES}

\section{TRANSLOCATION REGULATION}

Translocation of effectors by the T3SS is tightly regulated to optimize the infectious process of disease. It is well-established that YopN functions prior to cell contact in order to prevent the premature release of late Yops into the medium, thereby providing a measure of fidelity to substrate recognition by the T3SS. New data discussed here demonstrates that YopK also acts as a regulator of fidelity by preventing the export of middle Yops into host cells. How YopN and YopK coordinate these regulatory activities is unclear. Future endeavors will need to determine whether YopN and/or YopK are physically associated with the basal body and if so, with which proteins do they interact and are those interactions indeed required to regulate substrate specificity before and after cell contact? Likewise, YopK and YopE are both major regulators of translocation that function after they are injected into the host cell. YopE appears to exert its effect via manipulation of the actin cytoskeleton, while YopK associates with the translocation pore complex. How cytoskeletal changes influence the T3SS function, and whether these changes are channeled through the YopK-pore complex interaction is a mystery. Understanding the hierarchy and mechanisms of translocated regulatory proteins is an exciting new component of T3SS research.

\section{THE TWO-STEP TRANSLOCATION MODEL}

A new model for Yop translocation has been suggested recently: the "two step" translocation model (Akopyan et al., 2011; Edgren et al., 2012). In this model, middle and late Yops can be secreted via the T3SS and subsequently associate with the bacterial outer membrane where they aggregate into complexes of translocators and effectors. These complexes would have to be released from bacteria, diffuse across the space between the bacterium and host cell, and then interact with membranes of target cells. Translocators YopB and YopD would then mediate transfer of the effector Yops into the host cell. In support of this model, Yops 
have been known to autoaggregate to the bacterial surface when triggered after secretion in vitro (Darveau et al., 1980; Straley and Brubaker, 1981; Bolin et al., 1982; Yother and Goguen, 1985). In fact, the binding of Yops to the surface of the bacterium before the T3SS was discovered led researchers to believe Yops were outer membrane proteins and hence their name, Yersinia outermembrane proteins. It has also been shown that host cells can take up YopH-Bla coated on the surface of a $\Delta y o p H Y$. pseudotuberculosis mutant (Akopyan et al., 2011). Interestingly, the presence of the T3SS was necessary for this translocation to occur despite the fact that YopH-Bla was not expressed in the bacteria. This new "two step" model presents an interesting conundrum to the Yersinia field and to the research presented herein. Several questions remain unanswered. Do both methods of Yop delivery occur, and if so, which one is predominant in vivo? If the needle is not connected to the host as a continuous channel, then how is cell contact sensed in order to provide the critical signal to release the YopN regulatory blockade on late Yop secretion? If the injectisome is not involved in direct translocation of effectors into host cells, how are Y. pestis effectors YopK and YopE transmitting signals back to the bacteria? Do complexes of effector-Yops and translocator-Yops form pores that are subject to regulation

\section{REFERENCES}

Aepfelbacher, M. (2004). Modulation of Rho GTPases by type III secretion system translocated effectors of Yersinia. Rev. Physiol. Biochem. Pharmacol. 152, 65-77.

Aepfelbacher, M., Trasak, C., Wilharm, G., Wiedemann, A., Trulzsch, K., Krauss, K., et al. (2003). Characterization of YopT effects on Rho GTPases in Yersinia enterocolitica-infected cells. J. Biol. Chem. 278, 33217-33223.

Agbor, T. A., and McCormick, B. A. (2011). Salmonella effectors: important players modulating host cell function during infection. Cell. Microbiol. 13, 1858-1869.

Agrain, C., Callebaut, I., Journet, L., Sorg, I., Paroz, C., Mota, L. J., et al. (2005a). Characterization of a type III secretion substrate specificity switch (T3S4) domain in YscP from Yersinia enterocolitica. Mol. Microbiol. 56, 54-67.

Agrain, C., Sorg, I., Paroz, C., and Cornelis, G. R. (2005b). Secretion of YscP from Yersinia enterocolitica is essential to control the length of the injectisome needle but not to change the type III secretion substrate specificity. Mol. Microbiol. 57, 1415-1427.

Aili, M., Hallberg, B., Wolf-Watz, H., and Rosqvist, R. (2002). GAP activity of Yersinia YopE. Meth. Enzymol. 358, 359-370.

Aili, M., Isaksson, E. L., Carlsson, S. E., Wolf-Watz, H., Rosqvist, R., and Francis, M. S. (2008). Regulation of Yersinia Yop-effector delivery by translocated YopE. Int. J. Med. Microbiol. 298, 183-192.

Aili, M., Isaksson, E. L., Hallberg, B., Wolf-Watz, H., and Rosqvist, R. (2006). Functional analysis of the YopE GTPase-activating protein (GAP) activity of Yersinia pseudotuberculosis. Cell. Microbiol. 8, 1020-1033.

Akopyan, K., Edgren, T., Wang-Edgren, H., Rosqvist, R., Fahlgren, A., Wolf-Watz, H., et al. (2011). effectors in type III secretion. PNAS 108, 1639-1644.

Allaoui, A., Schulte, R., and Cornelis, G. R. (1995). Mutational analysis of the Yersinia enterocolitica virC operon: characterization of $y s c E, F, G, I, J, K$ required for Yop secretion and $y s c H$ encoding YopR. Mol. Microbiol. 18, 343-355.

Allaoui, A., Woestyn, S., Sluiters, C., and Cornelis, G. R. (1994). YscU, a Yersinia enterocolitica inner membrane protein involved in Yop secretion. J. Bacteriol. 176, 4534-4542.

Anderson, D. M., and Schneewind, O. (1999). Yersinia enterocolitica type III secretion: an mRNA signal that couples translation and secretion of YopQ. Mol. Microbiol. 31, 1139-1148.

Berger, C., Robin, G. P., Bonas, U., and Koebnik, R. (2010). Membrane topology of conserved components of the type III secretion system from the plant pathogen Xanthomonas campestris pv. Translocation of surface-localized

by YopK, YopE, and YopT? It is difficult to envision a scenario in which a two-step delivery method would be compatible with the regulatory roles that YopK, YopE, and YopT seem to have within host cells. Data presented herein strongly implicate these bacterial effectors in generating a feedback signal that originates within host cells, which in turn implies that there is a continuous channel whose ends are able to communicate and exact precise control over the timing, specificity, and amplitude of Yop delivery. Of course such a channel remains hypothetical, and future work needs to place an emphasis on developing tools to allow visualization of actively translocating injectisomes docked onto host cells, as well as a more detailed view of the pore complex architecture. Such technological advances are crucial for providing insight into these key aspects of injectisome assembly and function.

\section{ACKNOWLEDGMENTS}

We thank Zach Haga and members of the Marketon Laboratory for helpful discussions. Melanie M. Marketon acknowledges support from NIH Grant Number: R21AI083660. Rebecca S. Dewoody acknowledges support from NIH Grant Number: T32 GM007757.

vesicatoria. Microbiology 156, 1963-1974.

Bhakdi, S., Mackman, N., Nicaud, J. M., and Holland, I. B. (1986) Escherichia coli hemolysin may damage target cell membranes by generating transmembrane pores. Infect. Immun. 52, 63-69.

Bjornfot, A. C., Lavander, M., Forsberg, A., and Wolf-Watz, H. (2009). Autoproteolysis of $\mathrm{YscU}$ of Yersinia pseudotuberculosis is important for regulation of expression and secretion of Yop proteins. J. Bacteriol. 191, 4259-4267.

Black, D. S., and Bliska, J. B. (2000) The RhoGAP activity of the Yersinia pseudotuberculosis cytotoxin YopE is required for antiphagocytic function and virulence. Mol. Microbiol. 37, 515-527.

Blaylock, B., Berube, B. J., and Schneewind, O. (2010). YopR impacts type III needle polymerization in Yersinia species. Mol. Microbiol. 75, 221-229.

Blaylock, B., Riordan, K. E., Missiakas, D. M., and Schneewind, O. (2006). Characterization of the Yersinia enterocolitica type III secretion ATPase $\mathrm{YscN}$ and its regulator, YscL. J. Bacteriol. 188, 3525-3534.

Blocker, A., Jouihri, N., Larquet, E., Gounon, P., Ebel, F., Parsot, C., et al. (2001). Structure and composition of the Shigella flexneri 'needle complex', a part of its type III secreton. Mol. Microbiol. 39, 652-663.

Boland, A., Sory, M.-P., Iriarte, M., Kerbourch, C., Wattiau, P., and
Cornelis, G. R. (1996). Status of YopM and YopN in the Yersinia yop virulon: YopM of $Y$. enterocolitica is internalized inside the cytosol of PU5-18 macrophages by the YopB, $\mathrm{D}, \mathrm{N}$ delivery apparatus. EMBO J. 15, 5191-5201.

Bolin, I., Norlander, L., and Wolf-Watz, H. (1982). Temperature-inducible outer membrane protein of Yersinia pseudotuberculosis and Yersinia enterocolitica is associated with the virulence plasmid. Infect. Immun. 37, 506-512.

Braun, V., Neuss, B., Ruan, Y., Schiebel, E., Schoffler, H., and Jander, G. (1987). Identification of the Serratia marcescens hemolysin determinant by cloning into Escherichia coli. J. Bacteriol. 169, 2113-2120.

Brodsky, I. E., Palm, N. W., Sadanand, S., Ryndak, M. B., Sutterwala, F. S., Flavell, R. A., et al. (2010). A Yersinia effector protein promotes virulence by preventing inflammasome recognition of the type III secretion system. Cell Host Microbe 7, 376-387.

Broms, J. E., Edqvist, P. J., Carlsson, K. E., Forsberg, A., and Francis, M. S. (2005). Mapping of a YscY binding domain within the LcrH chaperone that is required for regulation of Yersinia type III secretion. J. Bacteriol. 187, 7738-7752.

Broz, P., Mueller, C. A., Muller, S. A., Philippsen, A., Sorg, I., Engel, A., et al. (2007). Function and molecular architecture of the Yersinia injectisome tip complex. Mol. Microbiol. 65, 1311-1320. 
Brubaker, R. R., and Surgalla, M. J. (1964). The effect of Ca++ and $\mathrm{Mg}++$ on lysis, growth, and production of virulence antigens by Pasteurella pestis. J. Infect. Dis. 114, 13-25.

Cheng, L. W., Kay, O., and Schneewind, O. (2001). Regulated secretion of YopN by the type III machinery of Yersinia enterocolitica. J. Bacteriol. 183, 5293-5301.

Cheng, L. W., and Schneewind, O. (2000). Yersinia enterocolitica TyeA, an intracellular regulator of the type III machinery, is required for the specific targeting of YopE, YopH, YopM and YopN into the cytosol of eukaryotic cells. J. Bacteriol. 182, 3183-3190.

Creasey, E. A., Delahay, R. M., Daniell, S. J., and Frankel, G. (2003). Yeast two-hybrid system survey of interactions between LEE-encoded proteins of enteropathogenic Escherichia coli. Microbiology 149, 2093-2106.

Darveau, R. P., Charnetzky, W. T., and Hurlbert, R. E. (1980). Outer membrane protein composition of Yersinia pestis at different growth stages and incubation temperatures. J. Bacteriol. 143, 942-949.

Davis, A. J., Diaz, D. A., and Mecsas, J. (2010). A dominant-negative needle mutant blocks type III secretion of early but not late substrates in Yersinia. Mol. Microbiol. 76, 236-259.

Day, J. B., Ferracci, F., and Plano, G. V. (2003). Translocation of YopE and YopN into eukaryotic cells by Yersinia pestis yopN, tyeA, sycN, yscB and $l c r G$ deletion mutants measured using a phosphorylatable peptide tag and phosphospecific antibodies. Mol. Microbiol. 47, 807-823.

Day, J. B., and Plano, G. V. (1998). A complex composed of $\mathrm{SycN}$ and YscB functions as a specific chaperone for YopN in Yersinia pestis. Mol. Microbiol. 30, 777-789.

Day, J. B., and Plano, G. V. (2000). The Yersinia pestis YscY protein directly binds YscX, a secreted component of the type III secretion machinery. J. Bacteriol. 182, 1834-1843.

Dean, P. (2011). Functional domains and motifs of bacterial type III effector proteins and their roles in infection. FEMS Microbiol. Rev. 35, 1100-1125.

DeBord, K., Lee, V. T., and Schneewind, O. (2001). On the Role of LcrG and LcrV during the type III targeting of effector Yops by Yersinia enterocolitica. J. Bacteriol. 183, 4588-4598.

Dewoody, R., Merritt, P. M., and Marketon, M. M. (2012). YopK controls both rate and fidelity of Yop translocation. Mol. Microbiol. 87, 301-317.

Dewoody, R., Merritt, P. M., Houppert, A. S., and Marketon, M. M. (2011). YopK regulates the Yersinia pestis type III secretion system from within host cells. Mol. Microbiol. 79, 1445-1461.

Diepold, A., Amstutz, M., Abel, S. Sorg, I., Jenal, U., and Cornelis, G. R. (2010). Deciphering the assembly of the Yersinia type III secretion injectisome. EMBO J. 29, 1928-1940.

Diepold, A., Wiesand, U., Amstutz, M., and Cornelis, G. R. (2012). Assembly of the Yersinia injectisome: the missing pieces. Mol. Microbiol. 85, 878-892.

Diepold, A., Wiesand, U., and Cornelis G. R. (2011). The assembly of the export apparatus (YscR, S, T, $\mathrm{U}, \mathrm{V})$ of the Yersinia type III secretion apparatus occurs independently of other structural components and involves the formation of an YscV oligomer. Mol. Microbiol. 82, 502-514.

Driks, A., and DeRosier, D. J. (1990). Additional structures associated with bacterial flagellar basal body. J. Mol. Biol. 211, 669-672.

Edgren, T., Forsberg, A., Rosqvist, R., and Wolf-Watz, H. (2012). Type III secretion in Yersinia: injectisome or not? PLoS Pathog. 8:e1002669. doi: 10.1371/journal.ppat.1002669

Edqvist, P. J., Olsson, J., Lavander, M., Sundberg, L., Forsberg, A., WolfWatz, H., et al. (2003). YscP and $\mathrm{YscU}$ regulate substrate specificity of the Yersinia type III secretion system. J. Bacteriol. 185, 2259-2266.

Erhardt, M., Namba, K., and Hughes, K. T. (2010). Bacterial nanomachines: the flagellum and type III injectisome. Cold Spring Harb. Perspect. Biol. 2:a000299. doi: 10.1101/cshperspect.a000299

Evans, L. D., and Hughes, C. (2009). Selective binding of virulence type III export chaperones by FliJ escort orthologues InvI and YscO. FEMS Microbiol. Lett. 293, 292-297.

Evans, L. D., Stafford, G. P., Ahmed, S., Fraser, G. M., and Hughes, C. (2006). An escort mechanism for cycling of export chaperones during flagellum assembly. PNAS 103, 17474-17479.

Fernandez-Lago, L., Gomez, M., Vizcaino, N., and Chordi, A. (1994). Analysis of the immune response to Yersinia enterocolitica serotype-O:9released proteins by immunoblot and ELISA. Res. Microbiol. 145, 553-561.

Ferracci, F., Day, J. B., Ezelle, H. J., and Plano, G. V. (2004). Expression of a functional secreted YopN-TyeA hybrid protein in Yersinia pestis is the result of $\mathrm{a}+1$ translational frameshift event. J. Bacteriol. 186, 5160-5166.

Ferracci, F., Schubot, F. D., Waugh, D. S., and Plano, G. V. (2005) Selection and characterization of Yersinia pestis YopN mutants that constitutively block Yop secretion. Mol. Microbiol. 57, 970-987.

Fields, K. A., Plano, G. V., and Straley, S. C. (1994). A low- $\mathrm{Ca}^{2+}$ response (LCR) secretion $(y s c)$ locus lies within the $\operatorname{lr} B$ region of the LCR plasmid in Yersinia pestis. J. Bacteriol. 176, 569-579.

Forsberg, A., Viitanen, A.-M., Skunik, M., and Wolf-Watz, H. (1991). The surface-located YopN protein is involved in calcium signal transduction in Yersinia pseudotuberculosis. Mol. Microbiol. 5, 977-986.

Fowler, J. M., and Brubaker, R. R (1994). Physiological basis of the low calcium response in Yersinia pestis. Infect. Immun. 62, 5234-5241.

Fowler, J. M., Wulff, C. R., Straley, S. C., and Brubaker, R. R. (2009). Growth of calcium-blind mutants of Yersinia pestis at 37 degrees $C$ in permissive $\mathrm{Ca}^{2+}$-deficient environments. Microbiology 155, 2509-2521.

Francis, M. S., and Wolf-Watz, H. (1998). YopD of Yersinia pseudotuberculosis is translocated into the cytosol of HeLa epithelial cells: evidence of a structural domain necessary for translocation. Mol. Microbiol. 33, 799-814.

Galindo, C. L., Rosenzweig, J. A., Kirtley, M. L., and Chopra, A. K. (2011). Pathogenesis of Y. enterocolitica and $Y$ pseudotuberculosis in human Yersiniosis. J. Pathog. 2011:182051. doi: 10.4061/2011/ 182051

Garcia, J. T., Ferracci, F., Jackson, M. W., Joseph, S. S., Pattis, I., Plano, L. R., et al. (2006). Measurement of effector protein injection by type III and type IV secretion systems by using a 13-residue phosphorylatable glycogen synthase kinase tag. Infect. Immun. 74, 5645-5657.

Ghosh, P. (2004). Process of protein transport by the type III secretion system. Microbiol. Mol. Biol. Rev. 68 771-795.

Goure, J., Broz, P., Attree, O., Cornelis G. R., and Attree, I. (2005). Protective anti-V antibodies inhibit Pseudomonas and Yersinia translocon assembly within host membranes. J. Infect. Dis. 192, 218-225.

Goure, J., Pastor, A., Faudry, E., Chabert, J., Dessen, A., and Attree, I. (2004). The V antigen of Pseudomonas aeruginosa is required for assembly of the functional PopB/PopD translocation pore in host cell membranes. Infect. Immun. 72, 4741-4750.

Grosdent, N., Maridonneau-Parini, I., Sory, M.-P., and Cornelis, G. R. (2002). Role of Yops and adhesins in resistance of Yersinia enterocolitica to phagocytosis. Infect. Immun. 70, 4165-4176.

Hakansson, S., Bergman, T., Vanooteghem, J.-C., Cornelis, G., and Wolf-Watz, H. (1993). YopB and YopD constitute a novel class of Yersinia Yop proteins. Infect. Immun. 61, 71-80.

Hakansson, S., Schesser, K., Persson, C., Galyov, E. E., Rosqvist, R., Homble, F., et al. (1996). The YopB protein of Yersinia pseudotuberculosis is essential for the translocation of Yop effector proteins across the target cell plasma membrane and displays a contact-dependent membrane disrupting activity. $E M B O J$ $15,5812-5823$

Hamad, M. A., and Nilles, M. L. (2007). Roles of YopN, LcrG and $\mathrm{LcrV}$ in controlling Yops secretion by Yersinia pestis. Adv. Exp. Med. Biol. 603, 225-234.

Hodgkinson, J. L., Horsley, A., Stabat, D., Simon, M., Johnson, S., Da Fonseca, P. C., et al. (2009). Threedimensional reconstruction of the Shigella T3SS transmembrane regions reveals 12 -fold symmetry and novel features throughout. Nat. Struct. Mol. Biol. 16, 477-485.

Hoiczyk, E., and Blobel, G. (2001). Polymerization of a single protein of the pathogen Yersinia enterocolitica into needles punctures eukaryotic cells. Proc. Natl. Acad. Sci. U.S.A. 98 , 4669-4674.

Holmstrom, A., Petterson, J., Rosqvist, R., Hakansson, S., Tafazoli, F., Fallman, M., et al. (1997). YopK of Yersinia pseudotuberculosis controls translocation of Yop effectors across the eukaryotic cell membrane. Mol. Microbiol. 24, 73-91.

Holmstrom, A., Rosqvist, R., WolfWatz, H., and Forsberg, A. (1995a). Virulence plasmid-encoded YopK is essential for Yersinia pseudotuberculosis to cause systemic infection in mice. Infect. Immun. 63, 2269-2276.

Holmstrom, A., Rosqvist, R., WolfWatz, H., and Forsberg, A. (1995b). YopK, a novel virulence determinant of Yersinia pseudotuberculosis. Contrib. Microbiol. Immunol. 13, 239-243.

Houppert, A. S., Kwiatkowski, E., Glass, E. M., Debord, K. L., Merritt, P. M., Schneewind, O., et al. (2012). Identification of chromosomal genes in Yersinia pestis 
that influence type III secretion and delivery of Yops into target cells. PLoS ONE 7:e34039. doi: 10.1371/journal.pone.0034039

Ibuki, T., Imada, K., Minamino, T., Kato, T., Miyata, T., and Namba, K. (2011). Common architecture of the flagellar type III protein export apparatus and F- and V-type ATPases. Nat. Struct. Mol. Biol. 18, 277-282.

Ide, T., Laarmann, S., Greune, L., Schillers, H., Oberleithner, H., and Schmidt, M. A. (2001). Characterization of translocation pores inserted into plasma membranes by type III-secreted Esp proteins of enteropathogenic Escherichia coli. Cell. Microbiol. 3, 669-679.

Iriarte, M., and Cornelis, G. R. (1998). YopT, a new Yersinia effector protein, affects the cytoskeleton of host cells. Mol. Microbiol. 29, 915-929.

Iriarte, M., and Cornelis, G. R. (1999). Identification of $\mathrm{SycN}, \mathrm{YscX}$, and $\mathrm{YscY}$, three new elements of the Yersinia yop virulon. J. Bacteriol. 181, 675-680.

Iriarte, M., Sory, M.-P., Boland, A., Boyd, A. P., Mills, S. D., Lambermont, I., et al. (1998). TyeA, a protein involved in control of Yop release and in translocation of Yersinia Yop effectors. EMBO J. 17, 1907-1918.

Isaksson, E. L., Aili, M., Fahlgren, A., Carlsson, S. E., Rosqvist, R., and Wolf-Watz, H. (2009). The membrane localization domain is required for intracellular localization and autoregulation of YopE in Yersinia pseudotuberculosis. Infect. Immun. 77, 4740-4749.

Jackson, M. W., Day, J. B., and Plano, G. V. (1998). YscB of Yersinia pestis functions as a specific chaperone for YopN. J. Bacteriol. 180, 4912-4921.

Jackson, M. W., and Plano, G. V. (2000). Interactions between type III secretion apparatus components from Yersinia pestis detected using the yeast two-hybrid system. FEMS Microbiol. Lett. 186, 85-90.

Journet, L., Agrain, C., Broz, P., and Cornelis, G. R. (2003). The needle length of bacterial injectisomes is determined by a molecular ruler. Science 302, 1757-1760.

Khan, I. H., Reese, T. S., and Khan, S. (1992). The cytoplasmic component of the bacterial flagellar motor. PNAS 89, 5956-5960.

Koster, M., Bitter, W., De Cock, H., Allaoui, A., Cornelis, G. R., and Tommassen, J. (1997). The outer membrane component, $\mathrm{YscC}$, of the Yop secretion machinery of
Yersinia enterocolitica forms a ringshaped multimeric complex. Mol. Microbiol. 26, 789-797.

Kubori, T., Matsushima, Y., Nakamura, D., Uralil, J., Lara-Tejero, M., Sukhan, A., et al. (1998). Supermolecular structure of the Salmonella typhimurium type III protein secretion system. Science 280, 602-605.

Kubori, T., Yamaguchi, S., and Aizawa, S. (1997). Assembly of the switch complex onto the MS ring complex of Salmonella typhimurium does not require any other flagellar proteins. J. Bacteriol. 179, 813-817.

Lavander, M., Sundberg, L., Edqvist, P. J., Lloyd, S. A., Wolf-Watz, H., and Forsberg, A. (2003). Characterisation of the type III secretion protein $\mathrm{YscU}$ in Yersinia pseudotuberculosis. YscU cleavagedispensable for TTSS but essential for survival. Adv. Exp. Med. Biol. 529, 109-112.

Lee, V. T., Anderson, D. M., and Schneewind, O. (1998). Targeting of Yersinia Yop proteins into the cytosol of HeLa cells: one-step translocation of YopE across bacterial and eukaryotic membranes is dependent on SycE chaperone. Mol. Microbiol. 28, 593-601.

Lee, V. T., and Schneewind, O. (1999). Type III machines of pathogenic yersiniae secrete virulence factors into the extracellular milieu. Mol Microbiol. 31, 1619-1629.

Ligtenberg, K. G., Miller, N. C. Mitchell, A., Plano, G. V., and Schneewind, O. (2012). LcrV mutants that abolish Yersinia type III injectisome function. J. Bacteriol. doi: 10.1128/JB.02021-12. [Epub ahead of print].

Marketon, M. M., Depaolo, R. W., Debord, K. L., Jabri, B., and Schneewind, O. (2005). Plague bacteria target immune cells during infection. Science 309, 1739-1741.

Marlovits, T. C., Kubori, T., Sukhan, A., Thomas, D. R., Galan, J. E., and Unger, V. M. (2004). Structural insights into the assembly of the type III secretion needle complex. Science 306, 1040-1042.

Mattei, P. J., Faudry, E., Job, V., Izore, T., Attree, I., and Dessen, A. (2011). Membrane targeting and pore formation by the type III secretion system translocon. FEBS J. 278, 414-426.

Mehigh, R. J., Sample, A. K., and Brubaker, R. R. (1989). Expression of the low calcium response in Yersinia pestis. Microb. Pathog. 6, 203-217.

Mejia, E., Bliska, J. B., and Viboud, G. I. (2008). Yersinia controls type III effector delivery into host cells by modulating Rho activity. PLoS Pathog. 4:e3. doi 10.1371/journal.ppat.0040003

Melen, K., Krogh, A., and Von Heijne, G. (2003). Reliability measures for membrane protein topology prediction algorithms. J. Mol. Biol 327, 735-744.

Michiels, T., and Cornelis, G. R. (1991). Secretion of hybrid proteins by the Yersinia Yop export system. J. Bacteriol. 173, 1677-1685.

Michiels, T., Wattiau, P., Brasseur, R., Ruysschaert, J.-M., and Cornelis, G. (1990). Secretion of Yop proteins by yersiniae. Infect. Immun. 58 2840-2849.

Minamino, T., Iino, T., and Kutuskake, K. (1994). Molecular characterization of the Salmonella typhimurium flhB operon and its protein products. J. Bacteriol. 176, 7630-7637.

Minamino, T., and Macnab, R. M. (2000). Interactions among components of the Salmonella flagellar export apparatus and its substrates. Mol. Microbiol. 35, 1052-1064.

Mohammadi, S., and Isberg, R. R. (2009). Yersinia pseudotuberculosis virulence determinants invasin, YopE, and YopT modulate RhoG activity and localization. Infect. Immun. 77, 4771-4782.

Montagner, C., Arquint, C., and Cornelis, G. R. (2011). Translocators YopB and YopD from Yersinia enterocolitica form a multimeric integral membrane complex in eukaryotic cell membranes. J. Bacteriol. 193, 6923-6928.

Mota, L. J., Journet, L., Sorg, I., Agrain, C., and Cornelis, G. R. (2005) Bacterial injectisomes: needle length does matter. Science 307, 1278.

Mueller, C. A., Broz, P., and Cornelis, G. R. (2008). The type III secretion system tip complex and translocon. Mol. Microbiol. 68, 1085-1095.

Mueller, C. A., Broz, P., Muller, S. A., Ringler, P., Erne-Brand, F., Sorg, I., et al. (2005). The V-antigen of Yersinia forms a distinct structure at the tip of injectisome needles. Science 310, 674-676.

Nans, A., Mohandas, N., and Stokes, D. L. (2011). Native ultrastructure of the red cell cytoskeleton by cryo-electron tomography. Biophys. J. 101, 2341-2350.

Neyt, C., and Cornelis, G. R. (1999). Insertion of a Yop translocation pore into the macrophage plasma membrane by Yersinia enterocolitica: requirement for translocators YopB and YopD, but not LcrG. Mol. Microbiol. 33, 971-981.

Olive, A. J., Kenjale, R., Espina, M., Moore, D. S., Picking, W. L., and
Picking, W. D. (2007). Bile salts stimulate recruitment of $\mathrm{IpaB}$ to the Shigella flexneri surface, where it colocalizes with IpaD at the tip of the type III secretion needle. Infect. Immun. 75, 2626-2629.

Payne, P. L., and Straley, S. C. (1998). YscO of Yersinia pestis is a mobile component of the Yop secretion system. J. Bacteriol. 180, 3882-3890.

Payne, P. L., and Straley, S. C. (1999). YscP of Yersinia pestis is a secreted component of the Yop secretion system. J. Bacteriol. 181, 2852-2862.

Perry, R. D., and Fetherston, J. D. (1997). Yersinia pestis - etiologic agent of plague. Clin. Microbiol. Rev. 10, 35-66.

Persson, C., Nordfelth, R., Holmstrom, A., Hakansson, S., Rosqvist, R., and Wolf-Watz, H. (1995). Cell-surfacebound Yersinia translocate the protein tyrosine phosphatase YopH by a polarized mechanism into the target cell. Mol. Microbiol. 18, 135-150.

Peters, K. N., and Anderson, D. M (2012). Modulation of host cell death pathways by Yersinia species and the type III effector YopK. $A d v$. Exp. Med. Biol. 954, 229-236.

Petterson, J., Nordfelth, R., Dubinina, E., Bergman, T., Gustafsson, M., Magnusson, K. E., et al. (1996). Modulation of virulence factor expression by pathogen target cell contact. Science 273, 1231-1233.

Picking, W. L., Nishioka, H., Hearn, P. D., Baxter, M. A., Harrington, A. T., Blocker, A., et al. (2005) $\mathrm{IpaD}$ of Shigella flexneri is independently required for regulation of Ipa protein secretion and efficient insertion of $\mathrm{IpaB}$ and $\mathrm{IpaC}$ into host membranes. Infect. Immun. 73, 1432-1440.

Riordan, K. E., and Schneewind, O. (2008). YscU cleavage and the assembly of Yersinia type III secretion machine complexes. Mol. Microbiol. 68, 1485-1501.

Riordan, K. E., Sorg, J. A., Berube, B. J., and Schneewind, O. (2008). Impassable $\mathrm{YscP}$ substrates and their impact on the Yersinia enterocolitica type III secretion pathway. J. Bacteriol. 190, 6204-6216.

Rosqvist, R., Forsberg, A., Rimpilainen, M., Bergman, T., and Wolf-Watz, H. (1990). The cytotoxic protein YopE of yersinia obstructs the primary host defense. Mol. Microbiol. 4, 657-667.

Rosqvist, R., Forsberg, A., and WolfWatz, H. (1991). Intracellular targeting of the Yersinia YopE cytotoxin in mammalian cells induces actin microfilament disruption. Infect. Immun. 59, 4562-4569. 
Rosqvist, R., Magnusson, K.-E., and Wolf-Watz, H. (1994). Target cell contact triggers expression and polarized transfer of Yersinia YopE cytotoxin into mammalian cells. EMBO J. 13, 964-972.

Rosqvist, R., Persson, C., Hakansson, S., Nordfeldt, R., and Wolf-Watz, H. (1995). Translocation of the Yersinia YopE and YopH virulence proteins into target cells is mediated by YopB and YopD. Contrib. Microbiol. Immunol. 13, 230-234.

Ross, J. A., and Plano, G. V. (2011). A C-terminal region of Yersinia pestis YscD binds the outer membrane secretin YscC. J. Bacteriol. 193, 2276-2289.

Sal-Man, N., Deng, W., and Finlay, B. B. (2012). EscI: a crucial component of the type III secretion system forms the inner rod structure in enteropathogenic Escherichia coli. Biochem. J. 442, 119-125.

Sample, A. K., Fowler, J. M., and Brubaker, R. R. (1987). Modulation of the low-calcium response in Yersinia pestis via plasmid-plasmid interaction. Microb. Pathog. 2, 443-453.

Sansonetti, P. J., Ryter, A., Clerc, P., Maurelli, A. T., and Mounier, J. (1986). Multiplication of Shigella flexneri within HeLa cells: lysis of the phagocytic vacuole and plasmid-mediated contact hemolysis. Infect. Immun. 51, 461-469.

Schroeder, G. N., and Hilbi, H. (2008). Molecular pathogenesis of Shigella spp.: controlling host cell signaling, invasion, and death by type III secretion. Clin. Microbiol. Rev. 21, 134-156.

Schubot, F. D., Jackson, M. W., Penrose, K. J., Cherry, S., Tropea, J. E., Plano, G. V., et al. (2005). Threedimensional structure of a macromolecular assembly that regulates type III secretion in Yersinia pestis. J. Mol. Biol. 346, 1147-1161.

Shao, F., Merritt, P. M., Bao, Z., Innes, R. W., and Dixon, J. E. (2002). A Yersinia effector and a Pseudomonas avirulence protein define a family of cysteine proteases functioning in bacterial pathogenesis. Cell 109, 575-588.

Shao, F., Vacratsis, P. O., Bao, Z., Bowers, K. E., Fierke, C. A., and Dixon, J. E. (2003). Biochemical characterization of the Yersinia YopT protease: cleavage site and recognition elements in Rho GTPases. PNAS 100, 904-909.

Skrzypek, E., and Straley, S. C. (1995). Differential effects of deletions in $l c r V$ on secretion of $\mathrm{V}$ antigen, regulation of the low- $\mathrm{Ca}^{2+}$ response, and virulence of Yersinia pestis. J. Bacteriol. 177, 2530-2542.

Sorg, I., Goehring, U. M., Aktories, K., and Schmidt, G. (2001). Recombinant Yersinia YopT leads to uncoupling of RhoA-effector interaction. Infect. Immun. 69, 7535-7543.

Sorg, I., Wagner, S., Amstutz, M., Muller, S. A., Broz, P., Lussi, Y., et al. (2007). YscU recognizes translocators as export substrates of the Yersinia injectisome. EMBO J. 26, 3015-3024.

Sorg, J. A., Blaylock, B., and Schneewind, O. (2006). Secretion signal recognition by $\mathrm{YscN}$, the Yersinia type III secretion ATPase. PNAS 103, 16490-16495.

Sory, M.-P., and Cornelis, G. R. (1994). Translocation of a hybrid YopEadenylate cyclase from Yersinia enterocolitica into HeLa cells. Mol. Microbiol. 14, 583-594.

Spreter, T., Yip, C. K., Sanowar, S., Andre, I., Kimbrough, T. G., Vuckovic, M., et al. (2009). A conserved structural motif mediates formation of the periplasmic rings in the type III secretion system. Nat. Struct. Mol. Biol. 16, 468-476.

Stainier, I., Bleves, S., Josenhans, C., Karmani, L., Kerbourch, C., Lambermont, I., et al. (2000). YscP, a Yersinia protein required for Yop secretion that is surface exposed, and released in low $\mathrm{Ca}^{2+}$. Mol. Microbiol. 37, 1005-1018.

Straley, S. C., and Bowmer, W. S. (1986). Virulence genes regulated at the transcriptional level by $\mathrm{Ca}^{2+}$ in Yersinia pestis include structural genes for outer membrane proteins. Infect. Immun. 51, 445-454.

Straley, S. C., and Brubaker, R. R. (1981). Cytoplasmic and membrane proteins of yersiniae cultivated under conditions simulating mammalian intracellular environment. Proc. Natl. Acad. Sci. U.S.A. 78, 1224-1228.

Straley, S. C., and Cibull, M. L. (1989). Differential clearance and host-pathogen interactions of YopEand YopK- YopL- Yersinia pestis in $\mathrm{BALB} / \mathrm{c}$ mice. Infect. Immun. 57, 1200-1210.

Straley, S. C., Plano, G. V., Skrzypek, E., Haddix, P. L., and Fields, K. A. (1993). Regulation by $\mathrm{Ca}^{2+}$ in the Yersinia low- $\mathrm{Ca}^{2+}$ response. Mol. Microbiol. 8, 1005-1010.

Sukhan, A., Kubori, T., and Galan, J. E. (2003). Synthesis and localization of the Salmonella SPI-1 type
III secretion needle complex proteins PrgI and PrgJ. J. Bacteriol. 185, 3480-3483.

Sundberg, L., and Forsberg, A. (2003). TyeA of Yersinia pseudotuberculosis is involved in regulation of Yop expression and is required for polarized translocation of Yop effectors. Cell. Microbiol. 5, 187-202.

Thomas, D. R., Francis, N. R., Xu, C., and Derosier, D. J. (2006). The three-dimensional structure of the flagellar rotor from a clockwiselocked mutant of Salmonella enterica serovar Typhimurium. J. Bacteriol. 188, 7039-7048.

Thorslund, S. E., Edgren, T., Pettersson, J., Nordfelth, R., Sellin, M. E. Ivanova, E., et al. (2011). The RACK1 signaling scaffold protein selectively interacts with Yersinio pseudotuberculosis virulence function. PLoS ONE 6:e16784. doi: 10.1371/journal.pone.0016784

Torruellas, J., Jackson, M. W., Pennock, J. W., and Plano, G. V. (2005). The Yersinia pestis type III secretion needle plays a role in the regulation of Yop secretion. Mol. Microbiol. 57, 1719-1733.

Trulzsch, K., Sporleder, T., Igwe, E. I., Russmann, H., and Heesemann, J. (2004). Contribution of the major secreted yops of Yersinia enterocolitica $\mathrm{O}: 8$ to pathogenicity in the mouse infection model. Infect. Immun. 72, 5227-5234.

Veenendaal, A. K., Hodgkinson, J. L., Schwarzer, L., Stabat, D., Zenk, S. F., and Blocker, A. J. (2007). The type III secretion system needle tip complex mediates host cell sensing and translocon insertion. Mol. Microbiol. 63, 1719-1730.

Viboud, G. I., and Bliska, J. B. (2001). A bacterial type III secretion system inhibits actin polymerization to prevent pore formation in host cell membranes. EMBO J. 20, 5373-5382.

Viboud, G. I., Mejia, E., and Bliska, J. B. (2006). Comparison of YopE and YopT activities in counteracting host signalling responses to Yersinia pseudotuberculosis infection. Cell. Microbiol. 8, 1504-1515.

Von Pawel-Rammingen, U., Telepnev, M. V., Schmidt, G., Aktories, K. Wolf-Watz, H., and Rosquist, R (2000). GAP activity of the Yersinia YopE cytotoxin specifically targets the Rho pathway: a mechanism for disruption of actin microfilament structure. Mol. Microbiol. 36, 737-748.

Wong, A. R., Pearson, J. S., Bright, M. D., Munera, D.,
Robinson, K. S., Lee, S. F., et al. (2011). Enteropathogenic and enterohaemorrhagic Escherichia coli: even more subversive elements. Mol. Microbiol. 80, 1420-1438.

Wong, K. W., and Isberg, R. R. (2005). Yersinia pseudotuberculosis spatially controls activation and misregulation of host cell Racl. PLoS Pathog. 1:e16. doi: 10.1371/journal.ppat.0010016

Wood, S. E., Jin, J., and Lloyd, S. A. (2008). YscP and YscU switch the substrate specificity of the Yersinia type III secretion system by regulating export of the inner rod protein YscI. J. Bacteriol. 190, 4252-4262.

Yip, C. K., Kimbrough, T. G., Felise, H. B., Vuckovic, M., Thomas, N. A., Pfuetzner, R. A., et al. (2005). Structural characterization of the molecular platform for type III secretion system assembly. Nature 435, 702-707.

Yother, J., and Goguen, J. D. (1985). Isolation and characterization of $\mathrm{Ca}^{2+}$-blind mutants of Yersinia pestis. J. Bacteriol. 164, 704-711.

Young, H. S., Dang, H., Lai, Y., Derosier, D. J., and Khan, S. (2003). Variable symmetry in Salmonella typhimurium flagellar motors. Biophys. J. 84, 571-577.

Zumbihl, R., Aepfelbacher, M., Andor, A., Jacobi, C. A., Ruckdeschel, K., Rouot, B., et al. (1999). The cytotoxin YopT of Yersinia enterocolitica induces modification and cellular redistribution of the small GTP-binding protein RhoA. J. Biol. Chem. 274, 29289-29293.

Conflict of Interest Statement: The authors declare that the research was conducted in the absence of any commercial or financial relationships that could be construed as a potential conflict of interest.

Received: 13 September 2012; accepted: 16 January 2013; published online: 06 February 2013.

Citation: Dewoody RS, Merritt PM and Marketon MM (2013) Regulation of the Yersinia type III secretion system: traffic control. Front. Cell. Inf. Microbio. 3:4. doi: 10.3389/fcimb.2013.00004 Copyright (c) 2013 Dewoody, Merritt and Marketon. This is an open-access article distributed under the terms of the Creative Commons Attribution License, which permits use, distribution and reproduction in other forums, provided the original authors and source are credited and subject to any copyright notices concerning any third-party graphics etc. 